COMMENT

https://doi.org/10.1057/s41599-019-0240-y

\title{
What guns mean: the symbolic lives of firearms
}

Jonathan M. Metzl ${ }^{1}$

\section{ABSTRACT}

This article presents an overview of the symbolic tensions underlying representations of firearms and gun-related violence. The essay frames central questions that deserve further interrogation: what larger social and political contexts surround guns? How do narrations of gun rights or gun trauma map onto larger scripts about matters such as identity, bias, racism, or nationalism? What meanings do guns accrue for people and communities when these guns are not shooting bullets or causing mortal wounds? The paper lays out disciplinary terrain required to address these questions, calling on expertize from the social sciences, humanities, and arts. 


\section{Introduction}

cademic research on guns often focuses on gun-related injuries and deaths, and for good reason-getting shot leads to profound real-world consequences. "Getting shot hurts," President Ronald Reagan once put it after surviving and assassination attempt. "No matter how hard I tried to breath it seemed I was getting less and less air. I focused on that tiled ceiling and prayed" (Reagan, 2016, p. 157).

Evidence suggests that shootings rise in correlation with increasing numbers of civilian owned firearms. Scholars use words such as "crisis" or "epidemic" to describe spiraling mortal costs of gun-related morbidity and mortality. A 2018 position paper by the American College of Physicians (Butkus et al., 2018) warned that "firearm violence continues to be a public health crisis in the United States that requires the nation's immediate attention" while detailing the daily toll of firearm violence "in neighborhoods, homes, workplaces, and public and private places across the country."

Gun-related injury and death is an urgent problem that plays out increasingly across the world, and often in particular ways in the United States-a country that has less than five percent of the world's population, but over forty percent of its civilian-owned guns (Small Arms Survey, 2018).

Yet solutions remain elusive. Gun supporters reject research suggesting policy solutions to gun-related morbidity and mortality because of what they call a "tainted public health model" biased against their interests (Faria, 2001). Pro-gun communities thus encounter public health research in the context of backlash against findings that highlight the risks of having too many guns, or that posit the failures of pro-gun policies (Gun Owners of America (2009); Lott, 2014; Hsieh, 2016) —without addressing the larger contexts of gun ownership. Meanwhile, leading public health organizations and medical groups decry the lack of funding for gun research, and the silencer it places on knowledge (Metzl, 2018).

The result is an often-predictable tug of war between the research community on one hand, and critics who assail anti-gun bias in academia on the other. Policy level approaches that aim to stem tides of rising rates of gun injury and death then struggle to develop strategies for bridging polarizing political divides about gun ownership and gun-related trauma. Gun researchers also often fail to communicate with people in communities where there are a lot of guns (Metzl, 2019).

Improving such communication requires understanding the complex valences that guns accrue for people and communities when these guns are not shooting bullets or causing mortal wounds; in other words, focusing not just on death data, but on life data as well. For instance, how do people in gun-dense regions narrate the roles that firearms play in their daily lives? Is there a pleasure in gun ownership? What stories do people tell about their weapons? Why do some people feel they need guns in their homes or neighborhoods, while others reject guns out of hand?

Guns also invoke larger questions about politics. What larger social and political contexts surround guns? How do narrations of gun rights or gun trauma map onto larger scripts about matters such as identity, bias, racism, or nationalism?

These types of questions get at the divergent ways that people talk and feel about guns, in addition to living with and dying from them. They aim to uncover what guns mean, in addition to what they do.

Addressing guns symbolically means recognizing ways that firearms emerge as powerful symbols shaped by history, politics, geography, economy, media, and culture, as well as by actors such as gun manufacturers or lobbying groups. Such an approach understands guns as both denotative entities made of real mass and that draw real blood, and as connotative cyphers whose associations trigger themes such as protection, danger, safety, identity, race, gender, class, erotics, oppression, or revulsion.

Scholars from beyond traditional biomedical fields have begun to address these complex issues. Sociologists and anthropologists speak to persons living in "gun country" to better understand the significances of firearms within families or social networks, or track expanding community undulations of gun-related trauma. Historians trace relationships between gun rights and political movements, and trace ways that gun economies map onto larger colonizing projects. Literary scholars use their expertise to detail how representations of guns are driven by larger cultural anxieties about race and gender. Artists use representations of guns and gun violence to catalyze discussions of issues such as protest, protection, or survivorship. Meanwhile, public health researchers utilize research about the social meanings of guns to better understand the role of culture in shaping debates on firearm regulations.

Emerging work thereby contextualizes the public health implications of civilian-owned firearms within larger attitudes, assumptions, or beliefs. By so doing, such work also illuminates ways that people talk, and often talk past one another, about the broader tensions and divisions signified by firearms. Such research also demarcates new opportunities for common ground in the midst of atomized and polarizing debates about the best ways to achieve safety for people, families, and communities.

\section{The symbolic lives of firearms}

What themes emerge from studying the symbolic lives of firearms?

Gun advocates describe ways that firearms represent forms of selfhood forged through the protection of home and family. Conservative U.S. author David French (2018) tells of obtaining guns to protect his wife and children after feeling threatened by strangers in the neighborhood where he and his family lived. French purchased guns to keep in his home, and soon began carrying a weapon in public as well. "You feel a sense of burning conviction," he writes, "that you, your family, and your community are safer and freer because you own and carry a gun." Books such as Chris Bird's Thank God I Had a Gun (2008) similarly narrate support for gun rights through anecdotal renderings of armed citizens who stand their ground to protect themselves, their loved ones, or their property against intruders. Bird describes "heroes" such as, "Barbara," who in her moment of need "was wearing a small Smith and Wesson five-shot revolver in an inside the waistband holster" and carrying her Winchester Defender shotgun when "she took a few steps outside...she could see two figures silhouetted."

These types of representations speak of tensions that public health advocates have at times been slow to recognize-namely, that policies that regulate or restrict firearm ownership often neglect to address beliefs about guns among people who own them. In pro-gun communities, guns convey familiarity and custom, and suggest connection to neighbors or notions of cultural heritage. Such associations in turn give particular charge to alarmist rhetoric warning that liberals, researchers, or particular politicians aim to "take away your guns"-the implication being that these persons would uproot your families and traditions as well. For sociologist Harel Shapira (2017), such associations also highlight how, in certain parts of the U.S., carrying a gun represents a central part of people's lives and the Second Amendment a key part of their identity. Sociologist Jennifer Carlson (2015) similarly describes a new category of "citizenprotectors" and a related honor code that emerged following the U.S. Supreme Court's Heller decision, which allowed increasing 
numbers of people to carry guns for the defense of self, family, and property.

Gun identity is often contextual as well, influenced by factors such as regulation, legal status, medical condition, or job title. Anthropologist Ken MacLeish opens his book, Making War at Fort Hood $(2013$, p. 3), with the story of a soldier on a "no weapon profile" and barred from all gun-related duties at on the military base because of a traumatic brain injury. Once he stepped off the Texas Army post, however, the soldier was free to purchase a Soviet-style semiautomatic "rifle with a blond wood butt stock and a slim bayonet folded under the barrel" at the gun store down the road, which he kept at the ready by the door of his offbase apartment to ward off intruders. No longer an armed soldier, he remained sentry of his civilian domain.

Guns also symbolize assumptions and anxieties about gender and socioeconomic class. Consider, for instance, that notions of patriarchal armed safety, self-reliance, and freedom also appear frequently in gun advertisements. "The Armed Citizen, Protected by Smith and Wesson" read one campaign in the NRA magazine American Rifleman (Smith and Wesson, 2018), while ads for the Tavor semiautomatic rifle claimed that the gun would restore the "balance of power" for men who owned it (Tavor SAR, 2013). Glock advertisements told men that owning their guns restored "the confidence to live your life" (Smith, 2014a, 2014b).

Communication studies professor Leonard Steinhorn (2014) reads these types of advertisements as signaling ways that gun manufacturers position their products as totems of manhood and symbols of white male identity in response to social and economic change. According to Steinhorn, working-class white men long benefited from racial and gender systems that gave them a monopoly over manufacturing and construction jobs. Starting in the 1960s, the civil rights and women's movements brought increased competition into these marketplaces, while at the same time wages and the availability of manufacturing jobs declined precipitously. These changes in the economic and social order left working-class white men feeling bypassed and "victimized" by "usurpers" such as women and people of color. "How do these white men restore the strength and prestige of their idealized past?", Steinhorn asks. "Through guns, which instill fear particularly among the urban and educated elites who hold the levers of power and status in society today."

Social scientists have been at the fore of furthering understandings of guns and gun violence in relation to the role of gender and masculinity (Bridges, 2017). Eric Madfis reads the male gender-mass shooter connection to "cultural standards" dictating how men are expected to react to stress (Kiesel, 2018), while Carlson's important research (2015) illustrates the complex ways that particular men use guns to navigate contexts of "social insecurity" about social and economic decline.

Guns also connote complex tensions, stereotypes, and anxieties about race. NRA rhetoric posits guns as protections against, in the words of CEO Wayne LaPierre, "bad guys," thugs, "terrorists and home invaders and drug cartels, and car-jackers" (Cox, 2014; Beauchamp, 2017). Similar language courses through John Lott's tome, More Guns, Less Crime (2010, p. 3) -a statistically inspired book narrated through stories about people like a woman who "shot and killed an armed man she says was trying to carjack her van with her and her 1-year-old daughter inside." The threat of gangs plays a major role in Bird's Thank God I Had a Gun, where Barbara, a suburban white woman, shoots at five "black" teenagers, killing a "15-year-old black male," in part because, as she explains it, "as far as I'm concerned, if you have five kids out at midnight, they are a gang" (2008, p. 184).

According to sociologist Angela Stroud (2015, pp. 33, pp. $88-89$, p. 96 , pp. 100-102), such rhetoric plays to histories in which guns function as symbols of white authority. When Stroud asked white permit holders why they felt they needed guns, they frequently replied with answers that highlighted a "criminal class" of people of color to justify gun ownership. "You hear about carjackings," one gun toting man told her. "Let's just say you pull up to a convenience store and there's some certain people outside that make you feel a little nervous, then you've got your gun there...to make yourself feel more comfortable." For Stroud, examples of white "good guys" who carried guns to protect against racial others were particularly important because most of the racialized altercations never actually happened. Rather, white gun owners imagined these encounters based on anxieties about persons of color. In such stories, gun ownership became a defense of internalized notions of racial order, as well as an external personal safety.

Society often responds differently when the "good guys" are not white. For instance, the U.S. political establishment mobilized to disarm African American gun owners for much of the nineteenth and twentieth centuries, and black leaders who advocated taking up arms in self-defense against white supremacist intimidation met with violent resistance. Robert F. Williams, president of the Monroe, North Carolina, chapter of the NAACP in the 1950s and early 1960s, was forced to flee to Cuba after being pursued by the FBI on fabricated kidnaping charges, and after advocating for "the right of Negroes to meet the violence of the Ku Klux Klan by armed self-defense" (Williams, 1962). Nearuniversal mainstream condemnation followed Malcolm X's claim (1964) that "article number two of the Constitutional amendments provides you and me the right to own a rifle or a shotgun." Republican politicians, including then-California Governor Reagan, swiftly moved to enact expansive new gun-control measures when Huey Newton and the Black Panther Party for Self-Defense advocated carrying guns in public-as permitted by California law at the time (Huey et al., 2002).

Black gun ownership represented a right of American citizenship and an essential component of self-protection for Robert Williams, Malcom X, and others. Williams saw armed "Negro self-defense" as central to strategies required "when an oppressed people show a willingness to defend themselves" against "the violence with which Negroes in the South are treated daily-nay, hourly" (Williams, 1962, pp. 4-5). Similar arguments resonate with present-day groups such as Black Guns Matter, an African American gun rights organization highlighted in articles by political journalist Jane Coaston-whose work also highlights the racialized underpinnings of the U.S. gun-control movement (Coaston, 2018). My own current research (Metzl, 2019) shows how American racial history lay the groundwork for differing responses to white versus African American open carry proponents in the present day: mainstream society reflexively codes white men carrying weapons in public as patriots, while marking armed black men as threats or criminals.

Guns also connote contested narrations of history, and become symbols of peculiar conceptions of nationhood as a result. U.S. gun manufacturers long promoted guns through myths of settlers and cowboys who tamed the Wild West, guns in hand. In 2017, journalist Francis Clines (2014) visited the NRA Firearms Museum in Virginia and found that "a poster figure of John Wayne... offers a greeting here at the gun museum's gallery door as he holds his Winchester carbine at the ready." In his book Gun Crusaders, sociologist Scott Melzer (2009, pp. 30-33) exposes the role of Wayne-style gunslingers as a mythology not of the 1800s, but of mid-20th-century gun advertisers and popular culture. Guns were "unquestionably part of white westward expansion," Melzer writes, "but the role of firearms in expansion has been greatly exaggerated," and in reality many settlers who traveled west found little use for firearms in their daily lives." 
Meanwhile, historian Priya Satia's expansive book, Empire of Guns (2018, p. 11) upends traditional tellings of the industrial revolution by showing the importance of Britain's prosperous gun trade to its imperial expansions. The book's sweeping narrative spans centuries and continents to uncover how gun capitalism brought about a world in which "lethal mechanical violence came to pervade modern existence."

Guns can function as symbols of resistance or markers of collective trauma. Artists Jonathan Ferrara and Brian Borrello launched a Guns in the Hands of Artists project (2016) in response to soaring gun homicide rates in New Orleans, Louisiana. In the project, painters, glass artists, sculptors, photographers, and poets used decommissioned guns from a gun buyback program to "stimulate thinking about guns and gun violence in America." Guns grew into a traveling, communitybased social activist art project that merged guns with art "as a vehicle for dialogue, as a call to action, and_ultimately_ as an agent of change." Similarly, Mexican sculptor and artist Pedro Reyes joined with British composer John Coxon to produce an "orchestra" of instruments cast from rifles and handguns decommissioned in the town of Ciudad Juarez (Phaidon, 2013).

Guns, bullets, and bullet holes also feature prominently in the work of Mexican artist Teresa Margolles-who meticulously chronicles the effects of the drug war on Mexican bodies (Grigorian, 2017; Phaidon, 2013). Nodding to Andy Warhol, American painter Nicole Eisenman's colorful images place the viewer in the eye of a gun's authoritarian gaze (Smith, 2016). South African artist Ralph Ziman photographs men holding brightly colored, beaded AK-47s to highlight the seductive lethality of the weapons and the "destructive cycle of the international arms trade” (O’Neal, 2014).

Los Angeles-based painter Henry Taylor's work chronicles the traumatizing effects of guns, bullets, and police violence on black bodies-his remarkable 2017 painting, The Times They Ain't A Changing, Fast Enough, captures the dying moments of Philando Castile, a black man shot by police while his girlfriend and daughter were in the car alongside him (Sargent, 2018).

American poet Danez Smith (2014a, 2014b) similarly eulogizes the traumatizing effects of racial and police violence on black men. His extraordinary poem, juxtaposing the black boy and the bullet, draws jarring synergy between the short lives of these two actors, and the interlinked politics that surround them. "Both spark quite the debate," read the poem's arresting final lines. "Some folks want to protect them/some think we should just get rid/of the damn things all together."

\section{The guns themselves}

Why do well-intentioned people find it difficult to agree on ways to address firearm related injury and death? The sources cited above cumulatively suggest that it is not just the politics surrounding guns that divide people-so do the guns themselves, and their connections to deeply charged existential issues.

Guns reflect and encapsulate histories and politics about race, gender, socioeconomics, and any number of charged themes that are better addressed head on-by fighting against racism or racially inflected gun messaging for instance, or against economic policies that undermine working class jobs-rather than by armed proxy.

Addressing guns symbolically allows guns researchers to address questions that are counterintuitive in addition to ones that are self-evident. In what ways to guns shape identities?, might be one such question. Or, in what ways are guns sublime? Such an approach also provides means of better understanding, and then pushing back on stigmatizing stereotypes that surround gun violence-such as the stereotypes of race promoted by the NRA, or assumptions that "mental illness" alone causes mass shootings (Metzl and MacLeish, 2015).

Uncovering the symbolic valences of guns also provides means for talking across political and social divides in moments of relative peacetime, rather than in phases of distress. Debates about the roles of guns in society often emerge after mass violence, such as after mass shootings. In the U.S., public opinion polls suggest that people become ever more entrenched in polarizing stances following these horrific events. One side pushes for reformed gun laws, while the other digs in, or, as data suggests, buys more guns and ammunition because of concerns about future regulations. Compromise remains elusive.

Frequently lost among the push and pull strategies, not just for implementing effective policies, but for talking to people whose cooperation is vital for effective gun policy to be put into practice. Strategies here might promote open dialogue about perceptions and misperceptions of risk, gun related and otherwise.

Guns injure and kill tens of thousands of people each year, and many of these injuries and fatalities are preventable. However, approaching guns as symbols illustrates the potential limitations of framing gun related morbidity solely as an epidemic or a public-health crisis for which policy solutions are the primary answer. While doing so rightly calls attention to a dire need for intervention, it also limits recognition of the deeper biases, currents, and fissures that shape what guns mean, and what they come to represent.

Guns undoubtedly signify a public health crisis. Too many people die and too many communities suffer lasting trauma, and often in patterened ways that public health expertize is designed to address. But scratch the surface, and it becomes increasingly clear that guns signal a social crisis as well.

\section{Received: 3 January 2019 Accepted: 20 February 2019}

Published online: 02 April 2019

\section{References}

Advertisement for the Tavor SAR (2013) American Rifleman. http://www.nxtbook. com/nxtbooks/nra/ar_201307/index.php?startid=41\#/42, Accessed 6 May 2018

Beauchamp Z (2017) This chilling NRA ad calls on its members to save America by fighting liberals. Vox. https://www.vox.com/world/2017/6/29/15892508/nraad-dana-loesch-yikes, Accessed 1 Jan 2019

Bird C (2008) Thank god i had a gun: true accounts of self-defense. Privateer, San Antonio

Bridges T (2017) The sociological explanation for why men in America turn to gun violence. Quartz. https://qz.com/1095247, Accessed 1 Jan 2019

Butkus R, Doherty R, Bornstein SS (2018) Reducing firearm injuries and deaths in the united states: a position paper from the American College of Physicians. Ann Intern Med 169:704-707

Carlson J (2015) Citizen protectors: the everyday politics of guns in an age of decline. Oxford, New York

Clines F (2014) The N.R.A. says, go ahead, make my fantasy. New York Times https://nyti.ms/2KH80SX, Accessed 1 Jan 2019

Coaston J (2018) She defended herself with a legally owned (and unloaded) gun Now she's facing two years in prison. Vox. https:/www.vox.com/2018/5/4/ 17311452/gun-rights-black-lives-matter-michigan-siwatu-salama-ra, Accessed 1 Jan 2019

Cox A (2014) The NRA Has Declared War on America. The Guardian. https:// www.theguardian.com/commentisfree/2014/apr/28/nra-war-on-americawayne-lapierre-indianapolis, Accessed 1 Jan 2019

Faria M (2001) The Tainted Public-Health Model of GunControl. Foundation for Economic Education. https://bit.ly/2HVEHdO, Accessed 1 Jan 2019

Ferrara J (2016) Guns in the hands of artists. Inkshares, Oakland

French D (2018) What Critics Don't Understand About Gun Culture: I carry a weapon-and it's tied me closer to my community. The Atlantic. https:// www.theatlantic.com/politics/archive/2018/02/gun-culture/554351, Accessed 1 Jan 2019 
Grigorian A (2017) "Irrigacion" by Teresa Margolles and drug wars in Mexico. http://photogrig.com/irrigacion-by-teresa-margolles-and-drug-wars-inmexico-2, Accessed 1 Jan 2019

Gun Owners of America (2009) Disarming the Data Doctors: How To Debunk The 'Public Health' Basis For 'Gun Control. https://gunowners.org/fs0401/, Accessed 30 Apr 2018

Hsieh P (2016) Why I Don't Trust Government-Backed 'Gun Violence’ Research. Forbes. https://www.forbes.com/sites/paulhsieh/2016/06/22/why-i-dont-trustgovernment-backed-gun-violence-research/\#3cc1121bced8, Accessed $30 \mathrm{Apr}$ 2018

Huey P, Newton H, Hilliard H, Wiese D (2002) The Huey P. Newton Reader. Seven Stories Press, New York

Kiesel L (2018) Don't Blame Mental Illness for Mass Shootings; Blame Men. Politico. http://politi.co/2mFNPKf, Accessed 1 Jan 2019

Lott J (2010) More guns less crime: understanding crime and gun control laws. Chicago Press, Chicago

Lott J (2014) Opinion: media cherry picks missouri gun data to make misleading case for more control. Fox News. https://fxn.ws/2chOxWR, Accessed 7 May 2018

MacLeish KT (2013) Making war at fort hood: life and uncertainty in a military community. Princeton University Press, Princeton

Malcolm X (1964) Malcolm X on The Second Amendment (1964/2014). https:// www.youtube.com/watch?v=hG1tlJBGMes, Accessed 1 Jan 2019

Melzer S (2009) Gun crusaders: the NRAs culture war. NYU Press, New York

Metzl J (2018) Repeal the dickey amendment to address polarization surrounding firearms in the United States. Am J Public Health 108(7):864-865

Metzl J (2019) Dying of whiteness: how the politics of racial resentment is killing the American Heartland. Basic Books, New York

Metzl J, MacLeish K (2015) Mental illness, mass shootings, and the politics of American firearms. Am J Public Health 105(2):240-249

O’Neal L (2014) Ralph Ziman Makes (Gun) Art, Not War. Ozy. https:/www.ozy. com/good-sht/ralph-ziman-makes-gun-art-not-war/6547, Accessed 1 Jan 2019

Phaidon (2013) Mexican artist creates gun orchestra. https://www.phaidon.com/ agenda/art/articles/2013/february/26/mexican-artist-creates-gun-orchestra, Accessed 1 Jan 2019

Reagan M (2016) Lessons my father taught me: the strength, integrity, and faith of Ronald Reagan. Humanix Books, New York

Sargent A (2018) Examining Henry Taylor's Groundbreaking Paintings of the Black Experience. Artsy. https://www.artsy.net/article/artsy-editorialexamining-henry-taylors-groundbreaking-paintings-black-experience, Accessed 1 Jan 2019

Satia P (2018) Empire of guns: the violent making of the industrial revolution. Penguin, New York

Shapira H (2017) Waiting for José: the Minutemen's Pursuit of America. Princeton University Press, Princeton
Small Arms Survey (2018) Global Firearms Holding. http://www.smallarmssurvey. org/weapons-and-markets/tools/global-firearms-holdings.html, Accessed 1 Jan 2019

Smith, Wesson (2018) American Rifleman. https://www.americanrifleman.org/thearmed-citizen, Accessed 1 Jan 2019

Smith D (2014a) Juxtaposing the black boy and the bullet. Split This Rock. http:// www.splitthisrock.org/poetry-database/poem/juxtaposing-the-black-boy-thebullet, Accessed 1 Jan 2019

Smith G (2014b) Glock's Confidence to Live Your Life" Campaign. Selling the Second Amendment. http://sellingthesecondamendment.com/glocksconfidence-to-live-your-life-campaign/, Accessed 1 Jan 2019

Smith R (2016) Nicole Eisenman, Fluidly Merging Past, Present and Future. New York Times. https://www.nytimes.com/2016/06/03/arts/design/nicoleeisenman-fluidly-merging-past-present-and-future.html, Accessed 1 Jan 2019

Steinhorn L (2014) White men and their guns. Huffington Post. https://www. huffingtonpost.com/leonard-steinhorn/white-men-and-theirguns_b_4419903.html, Accessed 6 May 2019

Stroud A (2015) Good guys with guns: the appeal and consequences of concealed carry. UNC Press, Chapel Hill

Williams R (1962) Negroes with guns. Stellar Classics, New York, 2017

\section{Additional information}

Competing interests: The author declares no competing interests.

Reprints and permission information is available online at http://www.nature.com/ reprints

Publisher's note: Springer Nature remains neutral with regard to jurisdictional claims in published maps and institutional affiliations.

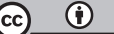

Open Access This article is licensed under a Creative Commons Attribution 4.0 International License, which permits use, sharing, adaptation, distribution and reproduction in any medium or format, as long as you give appropriate credit to the original author(s) and the source, provide a link to the Creative Commons license, and indicate if changes were made. The images or other third party material in this article are included in the article's Creative Commons license, unless indicated otherwise in a credit line to the material. If material is not included in the article's Creative Commons license and your intended use is not permitted by statutory regulation or exceeds the permitted use, you will need to obtain permission directly from the copyright holder. To view a copy of this license, visit http://creativecommons.org/ licenses/by/4.0/

(c) The Author(s) 2019 